\title{
Does Age Matter in HR Decision Making? Four Types of Age Policies in Finnish Work Organizations
}

\section{Anna Pärnänen'}

Ph.D Researcher, Labour Force Survey, Statistics Finland

\begin{abstract}
The extension of work careers is one of the key targets of social policy in the EU as well as in Finnish national policy-making. But how is this objective of lengthened work life received at the workplace level? This study examines the aim of extending working careers at an organizational level. The data comprise interviews with human resources managers, shop stewards, and employees reaching the end of their working life, conducted in ten Finnish work organizations. Four different age policy lines can be distinguished from the data. First, the age policy practices of manufacturing enterprises are very much alike in that a clear turn has occurred from favoring the unemployment pension path in the case of dismissals to extending working careers. Second, the age policy of public sector organizations encourages investment in extending the working careers of older employees, though young people are clearly preferred in recruitment. The third line can be found in private service sector enterprises that utilize age segmentation based on the age of their customers - young waiters for young customers, for example - while the fourth can be described by the words 'situation-specific' and 'passive'. No input is made into extending working careers and the unemployment route is used as the means of dismissal where needed. The study reveals that the organizations' age policies are strategic in nature: longer working careers are supported and older people are hired only if it is strategically sound. It can be said that workplaces currently determine the boundaries of who and at what age people are fit for work and of 'working age'.
\end{abstract}

\section{KEYWORDS}

Age policies / extending of work careers / organization / age discrimination / older employees / institutions / generational contract

\section{Introduction}

ne of the central aims of the EU's and Finland's national employment and pension policies is to prolong work careers, to postpone the average age of retirement, and to raise the employment rate of older workers. The demographic development in EU countries and the ageing of the workforce are factors that have brought these questions onto the political agenda. The ageing of the population is creating new economic and socio-political problems that need solutions. There are fears of labor shortages, economic recession, and the unsustainable growth of pension expenditures, and raising the effective retirement age is seen as a solution to these issues. If people worked longer, it

\footnotetext{
${ }^{1}$ Anna Pärnänen, Labour Force Survey, Box 5B, 00022 Statistics Finland, Finland.

E-mail: annaparnanen@gmail.com
} 
would both improve the dependency ratio and decrease pension expenditures (Andersen et al. 2007; Myles 2002).

The important factor behind the interest shown in older workers is the phenomenon of early exit from the labor market - that is, leaving work before the statutory retirement age - which has been a common labor market phenomenon since the 1970s in most EU countries (Kohli and Rein 1991). However, since the beginning of this century, there has been a positive turn in the employment rates of people aged between 55 and 64 in the EU25 countries, although the differences between EU countries are still significant (Pärnänen 2011).

In Finland, long-term developments have been similar to other EU countries: at its lowest, in 1994, the employment rate of the age group in question was as low as $34 \%$, although Finland has, however, managed to achieve significant positive development in this field. Besides its strong economic upswing followed by increased labor demand, this success story is also a result of the various tools developed to tackle the problem, such as introducing economic incentives for employers to discourage their using early exit routes and organizing campaigns against age discrimination (Ilmakunnas and Rantala 2005; The Many Faces... 2002). The most important tool is, however, the pension reform of 2005, which includes a new flexible retirement age and heavy economic incentives for older workers to remain in employment. The changes made in employment and pension policies are so profound that it can be said that there has occurred a clear turn to new age policies. Earlier, during the time of old age policies, the labor supply was regulated through pension policies, using mechanisms such as early pensions, which, especially the unemployment pension, functioned as tools used to alleviate the effects of structural change and the problem of unemployment (Ilmakunnas and Rantala 2005).

Despite the improved employment situation of older workers, however, the question of early exit from the labor market is still very relevant today. The aim to postpone the average age of withdrawal from the labor market is still on the political agenda both at the national level in Finland (Government Programme 2011) and at the EU level (Europe 2020 targets).

\section{Research question}

Policies can be changed, but can also the behavior of employers and employees be changed? New age policies have targeted two groups: first, employers, who are expected to implement personnel programs that would support their employees staying at work until retirement age and also promote the selection of older unemployed candidates when hiring new staff; and, second, the older age cohorts themselves, who are encouraged to avoid using early exit routes, meanwhile being supported in caring for their work competence and health.

However, choices about the length of working life are not made independently by either group; rather, it is the work organization itself that creates the micro-context wherein the decisions of both parties are made. In this article, I will examine how this objective of extended work life is received at the workplace level. What motivates employers to endorse long working careers and hire experienced rather than youthful staff, for example? I also investigate the extent to which organizations have age-specific 
human resource policies, and what kinds of processes are involved when decisions about staying at work or leaving work are made at the organizational level.

Here, human resources management (HRM) is understood as the organization's long-term plan for ensuring that a sufficiently large and sufficiently competent group of people carry out and develop its activities (Viitala 2002). The main concept used here is 'age policy', by which I mean the attitudes and the practices concerning older workers implemented in everyday HRM. The term 'policy' refers to coordinated, programmatic, and planned operations. Most of the organizations that participated in the study did not have age policies in that sense, but even if their practices were not specifically codified, clear differences in HRM based on age can be found when analyzing age-related decision making.

The article begins with discussion of the context of age policies in various types of organizations, followed by description of the qualitative data and research methods. The third section presents the study results: four different age policies are distinguished in the data. Conclusions are made in the final section.

\section{The context of organizations' age policies}

To examine the age policies in employing organizations, we must have an understanding of the kinds of factors that affect their formation (see Figure 1). During the course

Figure I: Context factors affecting age policies in employing organizations.

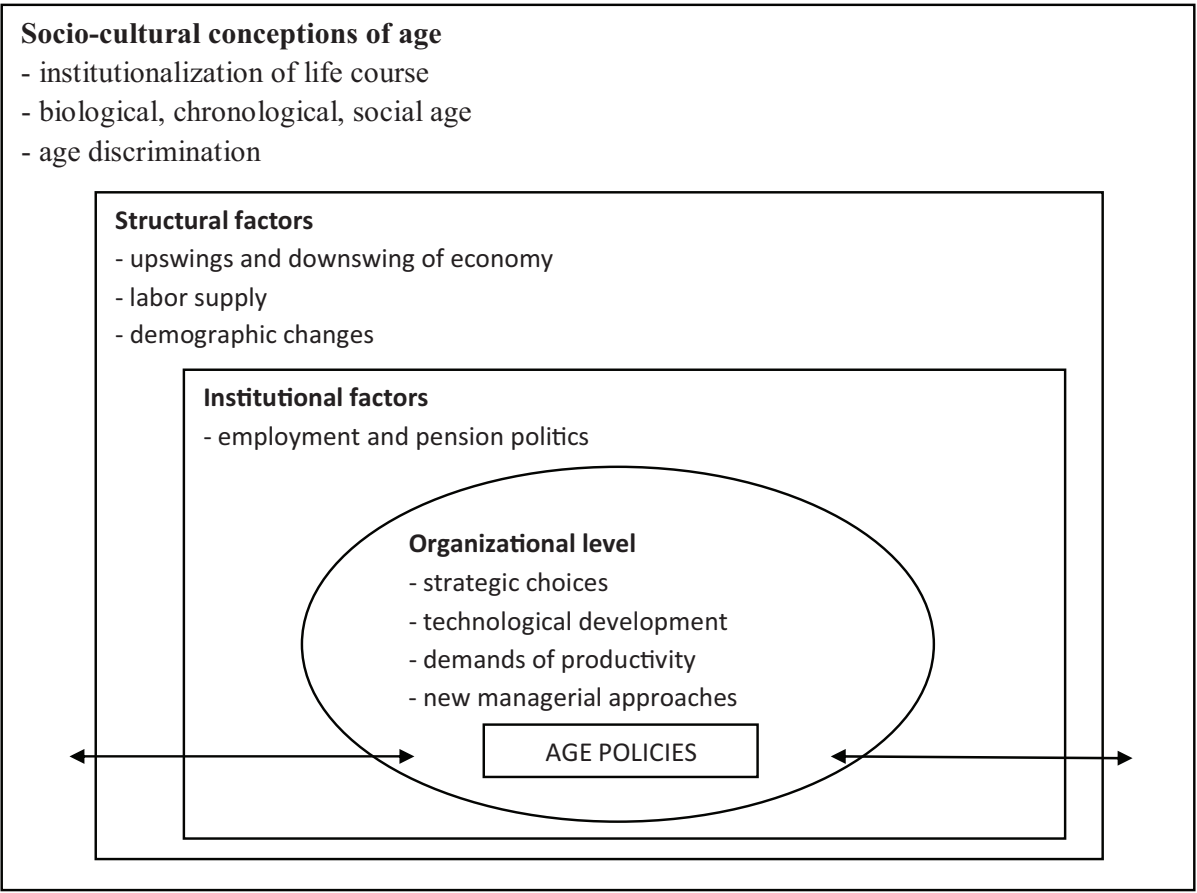


of research, I differentiated three important issues contributing to context: 1) sociocultural conceptions of age; 2) structural changes; and 3) the institutional frame. Furthermore, each case is affected by specific organizational conditions, where strategic choices and decisions to adopt new technological innovations, management tools, and internal changes take place.

\section{The institutional frame}

Employers, employees, and shop stewards make their decisions in a specific institutional context. To draw attention to institutions is to underline notions developed in new institutional theory-building (Immergut 1998; Schmid 2006) where it has been pointed out that the same actors with the same preferences could make different choices in different institutional frames. The second argument made by theorists of new institutionalism is that institutions have a normative nature; institutions can be used to guide people toward desired behavior. Third, relations between institutions and behavior are bidirectional. Institutions matter; although they are a result of human activity, they condition behavior and form that functional and interpretative framework within which people act and perceive their life (Kangas 2000). Here the pension and parts of the unemployment insurance system are examined as institutions that direct the decisions of organizational-level actors.

In Finland, there are several different institutional early exit pathways 1) the old age pension and gradual retirement, 2) disability, and 3) unemployment (Gould 1999). Before the pension reform of 2005 , the old age pension started at the age of 65 , but with the flexibility introduced in the reforms of that year it may take place between the ages of 63 and 68 (the exact time of exit to be decided by the employee him/herself). Reaching full retirement age and accepting the old age pension is seen as the norm and the use of other pathways is considered to be 'early' in comparison.

Here the different exit routes are not presented in detail (for fuller discussion, see Hytti 2002); however, one observation must be made. It is important to underline that the instigator of selection of an early exit pathway depends upon the pathway itself. In the use of routes 1) and 2) mentioned above, the employee is the instigator; the employee himself/herself must apply to make use of them. In addition, the disability pathway always needs a medical doctor's supporting statement and is highly regulated; therefore, it is not fully a 'free choice.' On the other hand, the unemployment pathway requires the employer to dismiss an employee and provide legal reasons for doing so. In terms of this study, the most important early exit route is the latter one: an unemployment pension at the age of 60 or the so-called unemployment pension tube at the age of 55 . After 2005 , the unemployment pension was abolished as such, but there is still a possibility for people aged 57 or over to leave work through the unemployment pathway since the 'tube' still exists.

As different studies have shown, multiple changes made to pension conditions raising and lowering the age limits of unemployment pension, introducing new individual early exit pathways, stricter medical criteria - have always been reflected in the volume and age of early exit (Hytti 1998; 2002; Järnefelt 2003; Rantala 2002). At an organizational level, the institutional frame indeed matters, both in the case of individuals' desire to leave work and in employers' goals to reduce their labor force. 


\section{Structural changes and changing working life}

Besides the institutional frame, changes in the economy and working life also create an important context for the development of age policies in employing organizations: structural factors such as demographic alteration (the ageing of the population for instance) and their effect on the labor supply form an important structural context to organizations' functions. Second, the business cycles of different branches of a national economy - their upswings and downswings - directly influence the demand for labor, while increased competition both in international and national markets is even more influential in the way in which business activities are conducted at the organizational level.

When examining the age policies of organizations, it is also important to think about the kind of work environment that would attract people to stay as long as possible. It seems that there is a shared understanding among researchers in the field that working life has changed substantially over recent decades. However, there are contradictory views on whether it has changed for the better or for worse (Bradley et al. 2000; Green 2006; Julkunen 2008).

Empirical evidence and arguments offered by more theoretical approaches (e.g., Siltala 2004) suggest today's working life is more demanding for employees than previously. It is argued that in today's work, higher qualifications are needed and that knowledge has become a more important feature of work. Furthermore, incessant and paced changes have become common features; there is increased flexibility in labor markets and therefore uncertainty regarding employment has become a normal state of mind. Reflecting this, attributes such as intensification, effectivization, and time pressure are often applied to describe the state of contemporary working life (Beck 2000; Casey 1995; Julkunen 2008; Lavikka 2004; Lehto and Sutela 2008; Sennett 1998).

However, empirical survey research also shows directions of change for the better. For example, Finnish employees have become increasingly white-collar and better educated and the number of people considering their work monotonous has decreased. Employees have increased opportunities to influence their work with regard to the division of tasks, working methods, and especially task content (Lehto and Sutela 2008). Furthermore, in many workplaces, it is actively aimed to diversify employees' occupational competence and additional education is widely offered (Melin and Mamia 2006). In this respect, the survey results collude with the suggestion that there is more independent work becoming available, with more opportunities for personally fulfilling and rewarding employment. Tuomo Alasoini (2010) has argued that compared with other countries, Finnish employees are rather satisfied with their personal working conditions and that there has been no significant change either for better or for worse. He claims that any problems are the result of bad organization and management rather than higher demands.

I see this change in working life as having an age aspect. Research has shown that there is a clear link between working conditions and remaining in work until retirement age: if the pressures to produce are raised, attachments to work tend to reduce. Psychological and physical strain has a similar impact. (Forma et al. 2004.) Furthermore, willingness to stay at work until retirement age decreases when there is increased time pressure, fear of more demanding work tasks in the future, and fear of the workload increasing to an unbearable level (Lehto and Sutela 2010; Pekka 2010; 
Saari 2008). Thus, in modern working life, there are features that support extended careers, such as opportunities for more independent activity, but there are also features that make the goal of late retirement especially challenging. The survey results show a negative development in the very features of working conditions that would encourage longevity of work life: reasonable work loads, moderate time pressure, and bearable mental and physical strain (Lehto and Sutela 2008). Even though more demanding work does not necessarily mean poor working conditions, these directions of change need to be tackled in order to achieve higher employment among older workers.

\section{Socio-cultural conceptions of age}

Chronological age is one of the basic variables in working life research and one of the key factors in this research also; concerns about the employment of certain age groups have caused a variety of socio-political and institutional initiatives. However, other dimensions of age can be distinguished that include biological, social, institutional, and subjective age (Aapola 1999). For this study, the important notion is that age is also a social characteristic. The kind of meaning age is given is linked to the age conceptions common to a community and specific to a particular historic time and its social and cultural factors (Vincent 1995). It follows that the age policies of organizations are not detached from socio-cultural conceptions of age. Based on age, we all have certain conceptions of other people that may be negative, positive or neutral; toward older workers they are more often negative (Taylor and Walker 1994; Vaahtio 2002).

In the research literature on working life, the cultural conceptions of age are usually discussed in relation to the question of age discrimination. The main argument is that employers make decisions based on inaccurate myths about the work ability and competence of older workers (Ilmarinen et al. 2003; see also Duncan 2001; McGoldrick and Arrowsmith 2001). Age discrimination is seen as a reason for the phenomenon of early exit as employers intentionally push older workers out of work through different early exit schemes and institutionalize prolonged unemployment due to their unwillingness to hire older persons.

Colin Duncan (2001) has discussed the question of age discrimination in employment extensively, noting that: 'Discrimination against older workers, not only with regard to exit policies but also with respect to recruitment and training restrictions, is deemed both irrational and commercially damaging. This view is currently so prevalent as to seem almost unchallengeable' (2001, p. 35). Yet, it is a position that needs further examination and for this purpose Duncan describes the different implications of employer policies toward older workers: whether positive or negative, in the perspective of commercial rationality, policies may either be rational or irrational. This raises the important question of why employers might act in a way that would be commercially irrational. This issue will be discussed below.

\section{Institutionalization of the life course}

There is one more issue that should be taken into account when examining age in work organizations, one which is directly related to socio-cultural conceptions of age: our 
perceptions of the life course and their links to welfare institutions. The pension system in the modern welfare state does not only frame (by limiting and offering possibilities) the decisions of employers and employees with regard to early exit, but it also creates and promotes the notion of commonly shared life phases. There is the time of preparation (childhood, youth), the time of activity (adulthood), and the time of retirement (old age). Here, I use the term life course institutionalization (Kohli 1986). In addition, modern life is segregated according to age: school for children, work for adults, retirement and old people's homes for the elderly (Julkunen 2003). The life course that consists of these phases can be seen as an independent dimension of the social order and thus as a social institution in itself and is 'organized around the system of labor that prevails in society' (Kohli 1986, p. 272), but as age relations and assumptions concerning them are temporal and local and tied to political, economic, social, and cultural contexts (Lallukka 2003), the modern culture of the welfare state is necessary in order to phase one's life course in this way. 'Retirement' as a phase of life is itself a modern achievement of the welfare state. The idea that work can be terminated on the basis of chronological age is historically new, developed in the context of the welfare state (Phillipson 1999). Assumptions of different life phases are relational; if there are changes in the living conditions or assumptions about a certain life phase, it affects the assumptions of another life phase (Bradley 1996; Hareven 1995). Today, 'retirement' as a phase of life has an important meaning in people's understanding of their later life.

\section{The data and research method}

The study material comprises interviews conducted in ten work organizations with human resources managers, shop stewards, and two or three older employees (eleven women, twelve men, all over 56 years). Human resources managers are seen as representatives of the employer and shop stewards as local-level union representatives, and both are considered representatives of the corporate system of industrial relations, with its conflicts, different interests, and agreements. These two representatives are the negotiating partners at the organizational level especially in case of redundancies, but also more broadly in many HRM issues. The interviews with older employees are used to provide an employee-level perspective on age issues. With the three different perspectives of employer, local union, and individual employee, I aim to offer a view of the situation that cuts across the organization though the main sources of information in this article are the interviews with human resources managers. All were conducted in five different towns in Finland at the beginning of the twenty-first century.

The organizations selected include seven private companies and three public organizations. In order to interview both male and female workers, different industries were included in the sample. The organizations are described later in more detail. The thematic interviews included questions aimed at investigating the role played by age in decision making in situations such as recruitment, redundancies, and other human resources issues. The attitudes to age of the human resources managers were also discussed during the interviews. The aim of the study is data-centeredness by applying grounded theory methodology (Strauss and Corbin 1998). The qualitative data are analyzed by coding it under different themes with the technical help of ATLAS.TI software (open coding). Each theme was further analyzed and new codes were created based 
on content analysis (axial coding). Finally, in selective coding, the data were organized around the main concept of age policies.

\section{Four types of age policies}

While analyzing the data, it became clear to me that different organizations operating in the same field had similar age policies. On the basis of past and present practices of recruitment, redundancies, and segmentation of work by age, I discerned four distinct categories corresponding to different employment fields in Finland. Therefore, instead of presenting each organization individually, the age polices of the organizations are presented by sector: manufacturing, public sector, and services.

\section{'Change of course' policy: manufacturing}

Among the case study organizations, there are two private companies that have clearly changed their pattern of age policies. The first one is a male-dominated company operating in the metal industry and the second a female-dominated food industry company operating on domestic markets. Both companies used early exit routes extensively during the 1990s and in the beginning of twenty-first century as a way to reduce the workforce. Thus, fewer than $1 \%$ of their employees were over 60 years. Age has actualized above all in redundancies, but to some extent also in recruitment.

Age polices followed the economic changes in industry and the work process. Downswings in business cycles were the most important reason for reductions in the workforce. However, the changes in work processes also reduced the need for labor and altered the qualification requirements of employees.

Two major turns in the history of the work process were recognized by those interviewed. First, automatization from the 1980s onward and more extensive use of information technology from the 1990s onward revolutionized work at the factories. The technological turn did not just rationalize and make the work process more effective, it also changed the nature of many tasks and introduced the need for retraining. Meanwhile, certain crafts and occupations disappeared entirely and were followed by reductions in the workforce. The second change, so-called structural change, was aimed at raising productivity and produced a concentration on core know-how, outsourcing, and an increased reliance on subcontractors. The result was more flexible production and the ability to adapt easily to changing business cycles. Concurrent with a clearly enunciated need to please stockholders, redundancies and lay-offs during the downswing came at shorter notice than before. Furthermore, both companies had become more international through cross-border investments and mergers.

What does this all mean when age is taken into consideration? First, especially in the metal industry, the know-how and experience of older employees became less relevant. The qualifications of older workers were not up-to-date anymore. Younger employees were seen as a more desirable workforce; they had systematically higher education than older ones, the latest knowledge from universities and educational institutions and better language skills. Besides, younger employees were regarded as more flexible and their resistance to changes was minor. Second, while the economic downswing and changes in 
work processes led to the need to reduce the workforce, the practical solution was to use early exit schemes and nearly all employees aged over 60 had exited the labor market via the unemployment pathway. According to the corporation's board, there was a need for redundancies, but as the whole process of redundancies took a while, the company was actually recruiting young persons at the same time early exit schemes were used. Birgitta Oden (1996, cited in Hellsten 1998) has argued that modernization leaps produce rejuvenation of the workforce. At least in the metal company the statement seems to hold true.

According to other research findings, the case study organizations seem to be typical of their sector, since unemployment exit pathways have been used extensively in the industrial sphere, especially when compared with other sectors (Hytti 1998; Järnefelt 2003).

At the time of redundancies, the use of the early exit schemes, particularly the unemployment pension and 'pension tube' was demanded by the local trade union and differed from the employer's first proposal for leavers. The list of people to be sacked formulated by the employer's representatives was seen as 'arbitrary', based on 'personal chemistry' between the foremen and workers (shop steward, metal industry). Alternatively, the demand that early exit pathways be used in redundancy processes was morally justified by the local trade union as, first, it was seen as a voluntary solution by the shop steward. Employees aged over 55 could choose to leave work and start to enjoy their pension earlier than planned, freed from hard labor.

Among the older workers themselves, however, there were two different attitudes toward early exit. On the one hand, people seemed to be willing to leave work earlier than 65. In fact, in the opinion of the human resources manager, the desire to leave was huge.

This was not just what the employer wanted, that we did not tell those people [older workers] to go, but ... I remember - I said that the so-called unemployment pension tube is now open, we had a total flow here, around 100 persons came, like right away - this means that the desire to leave was really big. (Human resources manager, metal industry)

On the other hand, there were considerations about whether older employees were under pressure to leave work earlier than they actually wanted. Tragic stories of those who had left were also known, as tragic as suicides. Regardless of these incidents, there can only be suspicions of the pressure to leave work put on older workers by younger colleagues, as nothing can be said for certain.

Well, yes, it was voluntary in the way that we were all asked but there were cases where there was criticism ... or not all were voluntary as there were some who wouldn't have left a few years back but now they were in actual fact forced to leave. And then they didn't dare, they were afraid how their work mates would react - that they did not have the nerve to stay, but they left - in the end. I'm sure that is what happened here. (Office worker, metal industry)

Second, the local union representative's demand that early exit schemes be implemented was actually the only way to influence how redundancies were carried out. It represented a form of resistance to the insecurity produced by continuous adaptation 
to business cycles, a lower threshold for redundancies (than earlier), and rationalization of the production. At the local trade union level, early exit pathways were seen as a way to control both the process of redundancies and the feeling of insecurity that continuous preparedness for adaptation and fear of redundancies created. Unemployment pensions and the unemployment pension tube were seen as forms of retirement, not as unemployment, per se, which they actually are. This was also due to the fact that those who left work through the unemployment tube did not have to fear being dropped to the basic unemployment benefit as they were entitled to income-related benefits until the old age pension. Use of early exit schemes was a way to distribute the risk of income loss between generations and an attempt to govern the risk of unemployment collectively. It also pointed out to the employer the fair way to act when making people redundant.

As shop steward I started from the position that every person's future must be secured and it is down to me and other shop stewards to decide whether to lay off a thirty-year-old father of a family or whether to put a 55-year-old man living with just his wife into the unemployment tube, it was in no way unclear to me which I would go for. (Shop steward, metal industry)

It can be said that there is a strong generational contract when it comes to the right to work, a clear expectation that older workers should give up their jobs for younger colleagues. The question of age discrimination, given that redundancies hit the oldest ones the hardest, was not discussed deeply. In the views of the local trade union, the use of early exit schemes was not only offering a pathway for older workers to start their 'third age'; it was also a way to show solidarity toward younger workmates. This tacit generational contract legitimated the process of starting redundancies among older workers.

It can be argued that while the decision of who should lose their jobs was a difficult one, actors at the organizational level relied on an institutional action model, in this case the use of the unemployment pathway. Furthermore, actors relied on social norms and socio-cultural conceptions of age regarding the 'right' to paid employment of people in different age cohorts and the position of people of different ages in relation to paid employment. On the one hand, institutional early exit pathways themselves embody socio-cultural conceptions of age, while on the other they create mental models of decision making. It is certainly apparent that institutional conditions produced solutions in which redundancies were directed foremost at later-life employees.

\section{Change of course in age policies}

Things changed quite swiftly, however. By the time of the interviews, there was a clear transformation in age policies in these two companies, though the period of redundancies among older workers was still quite recent. The new aim had become to keep employees at work longer by improving working conditions and avoiding the use of early exit. There appears to be four different reasons for this turnaround. First, the organizations had become aware of the need to prepare for a likely future labor shortage. Second, so-called tacit knowledge was lost through the use of early exit routes. Despite the 'new 
know-how' of younger employees, the older workers' experience was missed. Third, the use of early exit pathways was an expensive way to deal with redundancies. Fourth, the old policy was not good for the companies' reputations in a new social climate in which public debate encourages the longer retention of employees and raises questions about age discrimination.

This change of course in age policies was not easy to realize for two reasons. First, there were collective rules on how redundancies should be carried out - and also how they should be carried out in the future. The second difficulty was the fact that the use of early exit schemes had raised expectations of an earlier age of exit from work. Factory employees in the female-dominated food industry in particular already had expectations about their 'right' age of retirement. Some years earlier everyone over 60 was 'let go' at this factory, as in the paper and metal industries which had 'let' men at their age 'retire' through early exit schemes, and many of those remaining wanted the same kind of treatment. This led to a paradoxical situation: the local trade union was actually negotiating for redundancies, aiming that the company would promise to give notice to every person over 55 or 60 who wanted to leave work. The age of exit seemed to be a matter of personal choice. The proper age of exit was considered to be closer to 55 than 65 years, as indicated by interviews at all levels of employment.

Well, I set this dream for myself that when I'm 55, if this law is still in force, I'll think about whether to hand in my notice. But now I've started to think that I'll try to manage until I'm 60 and then get off. (Shop steward, food industry)

At first the company had accepted this usage of early exit on the part of the local trade union, but now it backed off, fearing that all its older workers would leave. Factory assembly line work does not necessarily appeal to younger people and while the level of education had risen, it is not easy anymore to get permanent and hard working labor such as that provided by these women in their fifties currently working at the factory.

It is certain that production couldn't cope if all our employees presently aged 50 to 59 left: [about a hundred] people suddenly deciding all at the same time that I don't want to work anymore. (Human resources manager, food industry)

The monotonous shift work at the factory is physically hard and these women felt they should be rewarded for their long work history by early retirement, particularly when comparing their own situations with that of the young and unemployed. There had been and there were employees considering handing in notice and in this way try to become eligible to unemployment pension or other exit pathway allowances. At the same time, if resigning was the only way to be released from work, the feeling of disappointment even betrayal - was strong.

Yes, that happens if you, like, hand in your notice - that's the end then if you have been close to 40 years with the company and always done your best and then you are forced to quit, you feel like, is this all that I'm worth? It feels a bit degrading. Here we are at 60, then [at that age] others have quit by handing in their notice, which I think is a pity, and a shame on the company if you have been there so long; you just should be able to retire in some other way. (Worker, food industry) 
The existence of institutional early exit pathways created expectations of early 'retirement.' They also strengthened the feeling of a right to a 'third age' at the same age as 'everyone else': while still healthy and in a physically good condition - 'early enough' so to say.

In examining early exit at the local level, certain conclusions can be reached. In both of the companies under analysis, the employer practices age policies that are strategically rational: using early exit routes when there is a need for redundancies due to a poor business climate and encouraging extended work life when threatened by a lack of competent workers. However, the expectations of employees and views of the local trade union have to be taken into account when deciding how redundancies are carried out. The use of early exit schemes has been a way to bring flexibility to the use of the workforce. There are collective moral rules - the 'generational contract' - that led to the use of early exit and the role of local trade unions has been significant. In most cases, economic and human interests conjoin in the use of early exit. But in some cases the use of early exit schemes has led to age-discriminating practices when redundancies take place.

\section{'Supporting older workers, recruiting young ones': the public sector}

The public sector has undergone similar changes to the private sector over the past two decades, with the recession of the 1990s leaving its mark on working conditions. As an outcome of a decrease in tax income and cuts in state subsidies, public sector organizations have been driven to higher productivity and tighter cost efficiency. However, compared with industry, age policies take a different form in the public sector. Three organizations - a middle-sized municipality, a state governmental department, and a middle-sized inter-municipal hospital - represent the public sector in this study, all of which are female dominated.

Since the recession years at the beginning of the 1990s, the human resource policy concerning public sector organizations has been tight. In the municipalities, the use of early exit schemes was common during the recession but not as extensive as in industrial companies and therefore redundancies were not widely discussed in the interviews. The tightening of budgets mostly manifested itself in reduced recruitment, a prohibition on hiring substitutes, and increased use of fixed-term employment contracts.

A decade of tightened recruitment policy has led to the absence of younger age cohorts and in-and-out flows of very young age groups as a result of the use of fixed-term contracts. This is also partly due to maternity and parental leaves where the majority of employees are women. This kind of HRM policy is a way to control employment costs and keep the budget in balance. As a result, the structure of these public sector organizations was heavily emphasized on the older age groups, with the average age of personnel ranging from 46 to 49 years. It is a development that is also reflected in the statistics: the age structure of the work force is the oldest in public sector organizations (Myrskylä 2005) where the use of fixed-term contracts is also proportionally higher (Lehto and Sutela 2008).

The fact that among older cohorts the majority of public sector employees are entitled either to old age pensions at a lower age or a lower occupational retirement age of 53 to 58 has inflated the situation, raising the fear that considerable know-how and 
practical knowledge might leave organizations before being transferred to younger generations. Thus the experience of older workers is seen as more relevant in public sector organizations than in industry or in private services. Above all, in many public sector occupations such as nurses, doctors, and civil servants, experience is valued not only by the employer but also by the customers.

Even if positive stereotypes are mainly connected with older employees, the fact that older workers were leaving work simultaneously has produced recruitment practices that grade young recruits more highly, meaning that recruitment has favored younger candidates. In this sense the organizations can be claimed to have age-discriminating practices. However, the 'old' age structure has been seen as a very legitimate reason for favoring younger people in recruitment, as noted by one informant:

We don't have any such rule and I cannot say that ... it is ageism if we say we don't hire anyone over fifty. But in practice ... In the background there is the age structure as well, meaning we have to get younger people besides our more experienced employees so that no sudden change can take place, because it is very harmful to the operation of this organization if several people leave the whole unit at the same time... (Human resources manager, municipality)

Second, despite a preference for recruiting young persons, the age policies of public sector organizations emphasize the need to keep older workers at work as long as possible. The practical methods used to encourage older employees to stay involve the maintenance of work capacity and a readiness to accept flexible working time arrangements. However, the institutional frame limits the possibilities to create incentives within the pension system for those who are prepared to stay longer since the majority of older employees are entitled to a full pension at the time they reach their occupational retirement age.

In summary, it can be said that the public sector values older-aged workers more highly than the industrial sector, but regrets the absence of younger ones who are expected to bring in the latest education and boost the organization with new ideas and more competitive attitudes. There has been a constant fear of losing the competition for younger workers entering the labor market to the private sector, as the private companies are able to offer better wages.

\section{'Age as marketing factor' policy: the service sector}

The two service sector organizations examined here are a hotel/restaurant chain and a retail store chain, both of which were doing well financially at the time of data collection and expanding their production of services. These organizations had also experienced changes both in working conditions and in tightened market competition: for the restaurant chain the main reason for the latter was the loosening of highly regulated Finnish alcohol policies, while for the retail store chain the increased competition was a result of foreign companies' invasion of Finnish markets and also an overall aim for higher profits.

As labor costs accounted for the greatest part of overheads, the tightening of competition led to the need to cut expenditures in that area in particular. Mostly this was 
done by switching full-time employees onto part-time contracts and hiring new employees on a part-time basis, a development reflected in the statistics (Hulkko and Pärnänen 2006). The use of part-time labor was a strategically important part of service production: electronic points of sale collected databases on customer frequencies that enabled adaptation of labor to customer visits, only possible if employees were employed on a part-time basis. The change in working times was seen as the most prominent change in working conditions in the service sector.

As part-time work is a desirable form of employment for younger people, particularly students, the age structure of the companies was heavily weighted toward younger cohorts and the age of the personnel was the lowest studied: 36 years on average in the retail company while in the restaurant/hotel company $90 \%$ were aged between 20 and 40. Thus the use of early exit is not the issue here, but the question of age has become important for sales planning and segmentation of work by age. As marketing is based on segmentation of consumer groups in this field, age becomes an important factor and the age of personnel aims to reflect that of the customers. For example, in restaurants younger employees are seen to be more suitable in the so-called night business in discos and night clubs, while older workers and the middle-aged, especially women, are best placed in taverns and public houses with regular customers.

If you know this bar business, from nine in the morning, it is for heavy drinking regular customers like a second home. They are not alcoholics, just heavy drinkers. You just have to be there; you can't put a thirty-year-old guy with an earring behind the bar, can you? Because their sets of values are so very different. He looks down on those customers and no customer can take that. This means that we look for workers of mature age, mainly women - say at around 40-50 they are at their best. (Human resources manager, restaurant and hotel services)

In the retail company, age was also an important attribute of the workers. In this company the age structure of regular customers was higher than that of the personnel. This was seen as a problem in the company, where it was felt that the age structures should be as compatible as possible. The argument for this is that customers are more willing to buy from a salesperson near their own age.

AP: Your clientele has an effect on the age of your personnel?

$\mathrm{H}$ : Yes, it has.

AP: Why?

$\mathrm{H}$ : It is quite natural, that, er ... if in walks a middle-aged customer, a typical regular customer, they would rather approach a salesperson of their own age than a 20-yearold, because of such things as confidentiality, and they can easily get the feeling that a young person may not know [what they want] as well as that slightly older one. (Human resources manager, retail trade)

As the age of regular customers was more middle-aged than young, the aim was to raise the number of older employees via two strategies: first, existing older workers were encouraged to stay longer through maintaining work capacity and with the help of practical solutions. It was possible to transfer to lighter work tasks or to go onto a part-time pension, and refresher courses especially for older employees were organized. These 
practices were also intended to lower the number of employees exiting work through a disability pension, which had become costly for the company. The second method was targeting recruitment toward older employees. Foremen were encouraged to hire the older of two equal candidates, for example, and this company was the only one where workers had managed to re-enter employment at the age of 55. However, even though this kind of age segmentation was actively maintained, it must be remembered that the majority of both service companies' employees were under 40 years. This was partly caused by the dominance of part-time work that drove employees to other branches and partly due to working conditions: shift work, low pay, and physical demands, as well as night work, smoking, and disorderly customers in restaurants pushed people out of the sectors. Work is only available when the restaurants or shops are crowded; during slow times people are sent home while at work itself, there is no time to take a break. The managers in both the restaurant and retail industries considered the fields as offering short-term employment prospects on the way to something else.

In summary, it can be pointed out that the age of personnel in the service sectors matters in sales planning, as part of the company image and in organizing customer services. There is a clear segmentation of work based on age of personnel and the use of part-time labor rejuvenates the age structure of the industries concerned.

\section{Private services II: passivity and favoring younger workers}

Three private sector companies - a local bank, a media business, and a local bus company - are the last to be analyzed here. The companies are rather different from each other in terms of the fields in which they operate and the age, gender, and educational structure of their personnel. Still, the age policies of the companies are rather similar. All companies were doing well economically at the time of data collection, although this was not emphasized in the interviews. The age structure was the most youthful in the local bus company where over $40 \%$ of the personnel were under 40 years, with only $4 \%$ of female personnel. The oldest age structure was in the female-dominated bank where the average age was 47.6 while in the media business both the age and gender structure were even.

Changes in working conditions were similar to other organizations examined. The biggest changes were the introduction of new information technology, more intensive control by the employer, and increased time pressure. These changes meant different things in different companies. In the bank, the new information technology has changed work remarkably. As customers now pay their bills and do their other daily banking business on-line, the 'simple' customer service tasks have disappeared, to be replaced by those dealing with investments, savings, and loans, which creates a need for new know-how and better education. The work was described as hectic, the need to learn new things was constant, and there was need for ongoing updating of requirements. Follow-up of results was also stricter than previously. New technologies were also used in order to control the amount of work each person was doing since every employee had to report daily on how they had used their working time.

Similar new controls have been adopted in the bus company as well. On-board recorders collect data on how long driving through each route takes. When it was noticed that the existing timetables made it possible for drivers to have short breaks at the end 
of each route, timetables were tightened, which created difficulties in coping among personnel. Physical strain and health problems were considered the biggest preventives to staying at work until retirement age. Technology has changed work in the media business as well, as new technological solutions have made timetables tighter. The development of new digital media produced pressure to develop new services for customers and created new work tasks. The basis of journalistic work was still, nevertheless, the same and there was a certain freedom to do one's job.

The three companies under investigation differ from each other when examined in terms of the way early exit pathways have been used. In the bank, there were extensive redundancies during the 1990s and the unemployment pathway was used widely, which was one reason why there were no employees aged over 60. As in the metal company, here also there were contradictory views about whether leaving work through the unemployment tube had constituted a voluntary or forced exit. More importantly, the threat of redundancy was constantly in the air in the bank. Every year calculations were made comparing the number of staff to the amount of work done and if there were too many resources, redundancies followed. This constant analysis of the correct number of personnel created a strong feeling of insecurity. Older workers in particular felt that they were on 'borrowed time' since they were constantly under fear of losing their jobs. This company is a good example of how older workers experience the same kind of insecurity as younger employees working in fixed-term contracts.

I've been under threat all the time; of course I've understood [...] that my job hasn't been secure at all. None of us have it safe and it's a thing that's affected our motivation in a big way. Today I feel a bit better about it, but at some point I was really anxious that this applies to me as well, when you look at how they laid off people starting from the oldest ones. (Customer advisor, bank)

In the other two companies, the unemployment pathway did not play such a role. In the local bus company, it was mainly the disability pathway that was used. In the media business, early exit had been used in the past, but it was not a relevant issue at the time of the interviews.

\section{Recruitment: favoring the young}

What is common to these three companies when their age policies are examined? First, it is clear that all of them favor younger people in recruitment. In the bank, the reason for this practice was the same as in the public sector: an old age structure. There was a need to rejuvenate the personnel. In the media business, the jobs open were mainly fixed-term ones and these were considered to be positions suitable for younger employees and were, therefore, mainly offered to people in that age group. The local bus company favored younger recruits purely because they were cheaper workers. Furthermore, since disability pensions were the most used early exit pathways, by recruiting young persons the company aimed to avoid those costs. Work as a bus driver was seen as physically taxing, and it was considered that young people could handle the stress better. They were also more willing to work during the evenings and at nights. In all of the firms, this practice of favoring younger people in recruitment was presented in the interviews as a 'natural' 
way of acting. The role of age in recruitment was not seen as problematic. Compared with the public sector, there was no hesitation about whether this was a good practice and there was no discussion about possible age discrimination.

The second common feature of age policies was that in all of the three companies, there was a certain passiveness in the matter of prolonging work careers. None of the companies were making much effort to support older workers in staying employed but neither were there strong incentives to get rid of them. Even though there was a readiness to make reductions in the bank and the reductions were directed toward older workers, these were not made on a large scale. I assume that these companies are representative of the average firm in Finland: age is not a matter of discussion and age-related decisions are made without problematizing their age-relatedness.

The age policies in such companies are passive and based on ad hoc decisions because there is no strategic need either to support staff staying longer at work (compared with the public sector) or to hire older ones (compared with the retail company). In the case of redundancies, it is a strategically sound solution to use early exit pathways since it is also a way to renew personnel. Furthermore, recruiting only younger employees is strategically rational since this makes it possible both to rejuvenate personnel and to minimize the costs of wages and disability pensions. Thus, despite a certain passiveness, even here age policies are related to cost-effectiveness and the optimization of the age structure.

\section{Conclusion}

The main findings of the study presented here lie in the four different types of age policies distinguished during empirical research, and concerning which I also have four main arguments.

First, I argue that age policies of organizations take their form as a result of strategic choices. Hanna Liikanen (1998) has shown that in the enterprises she studied, working time policy, especially flexibility of working time, is based on senior management's strategic planning. When the state relaxed its control on working time, the slack was increasingly taken up by organizations. In the surveyed enterprises, new working time arrangements were seen as a conscious rationalization of working time, which was triggered by an enterprise's struggle to be competitive. Making working time flexible was part of an enterprise's whole operation and objectives - not a separate issue. The senior management representatives interviewed by Liikanen did not place working time arrangements on the list of their most important issues, but rather were examined as a kind of secondary factor together with effectiveness, customer orientation, speed, and commitment of employees.

In my view, these two different issues, working time and age policy, can be regarded as analogous factors, part of the strategic planning of an organization. In the data examined by this study, age was explicitly presented as a strategic part of human resources policy. Age policies are not policies in the sense that they would be programmatic, considered, and well-grounded. Rather, age policies have developed more as part of strategic decision making as organizations adapt themselves to their changing operating environment. Age policies - that is, established practices based on employees' age - can be identified in the activity of organizations. Age policies are part of the competitive strategy 
of organizations, the objective of long-term human resources planning and efficiency, and organizational changes in work practices. Thus, age policies cannot be completely separated as a specific research question, but rather are intertwined with general changes in working life. Therefore, age policies are a secondary factor which should be examined together with other working life and labor market factors.

Age policy becomes strategic through the fact that to implement its competitive and operational strategy successfully, an enterprise has to do it primarily via its personnel. The age of the personnel is significant in how well an organization can carry out its operating plan. That means how well the organization can retain the employees it wants and needs (industrial enterprises), how well it can transfer knowledge (public sector), and answer customers' wishes (service sector). Furthermore, the enforced quantitative flexibility of the labor force has been mostly age-related. The different ways of enforcing the quantitative flexibility of the labor force and different strategic HRM decisions have produced different age structures in different industries. The age policies of organizations are, above all, influenced by the current economic situation and changes in the labor market (e.g., threat of labor shortage), the current age structure of the organization, and the age segmentation of services. A condition for age policies that would support people staying longer at work is that they benefit the organization itself. Predictably, those organizations that have a great strategic interest in keeping older staff at work have been the most commendable in implementing the kind of age policy favored by the policy-makers.

My second argument concerns age discrimination. As mentioned above, Colin Duncan (2001) has asked whether age-discriminating policy is actually irrational for employers. Based on this study, it can be argued that there are clear age-discriminating practices, especially in recruitment, among nearly all of the companies examined and this was because it was a rational action for the companies. This practice partly explains why re-employment is so difficult among older workers.

Third, I argue that early exit and prolonging of careers must be examined in relation to welfare state institutions, institutionalization of the life course, and promises 'made' by the pension system. Raija Gould and Laura Saurama (2003) have suggested that there have been three paradigmatic changes in the Finnish pension system. They summarize the changes by stating that a policy that highlighted early exit as a social right was replaced by a paradigm that emphasizes both a duty to work and individual flexibility. I argue that these institutional changes have had two kinds of consequences. First, the earlier long-term early exit policy has strengthened the idea of a third age as a socially constructed phase of life. In the organizations studied here - and more widely in Finland, I would argue - leaving work earlier became both socially widely accepted and created expectations of early exit. Early exit became a social right - whenever the employee so wanted. The second consequence was an increase in insecurity among older employees. As the institutional conditions, especially the unemployment pathway, directed both employers and local trade unions to use early exit pathways in the case of redundancies, early exit became a shared experience of certain generations. Willingness to stay at work, long experience, or competence did not guarantee one's work place until the retirement age. Rather, age has become a labor market risk at the end of the work career.

I view this tacit generational contract as written into institutional arrangements. The unemployment pathway was created in order to solve the problem of unemployment and it was negotiated between tripartite parties (Gould 1999). On the one hand, 
the aim was to reduce the labor supply and, on the other, the solution supported structural changes in the labor market as a less educated generation was withdrawn from the labor market (Gould 2002; Hytti 1998). While the solution tackled the problem of unemployment, there was simultaneously a written-in understanding of the primary right of younger people to paid employment. Early exit was seen more as a gift from a rich-enough welfare state and as a social right rather than an age-discriminating practice.

Assumptions of different life phases are formed in relation to each other. If there are changes in living conditions or assumptions made of a certain life phase, it affects the assumptions of another life phase (Bradley 1996; Hareven 1995). As the age of exit from the labor market has lowered and increasingly more people are outside the labor force at a younger age - that is, in the place belonging to old age - ideas about old age and the working age change. These institutionalized conditions have affected both the understanding of who is considered a 'working age person' and who is considered a 'retirement age person.' I claim that early exit has made the idea of the 'working age person' younger for employers as well as employees themselves.

John Myles (2002) notes that institutions remarkably modify cultural preferences and also that it is a surprise how fast lower retirement ages have become institutionalized. To change this kind of norm other things are needed in addition to cutting down incentives. That is because both employers and employees tend to create economic and social expectations around anticipated retirement age (Guillemard 2001). Workplaces currently determine the boundaries of who and at what age people are fit for work and of 'working age' more generally. It can be said that the underlying theme of the whole objective of extending working careers is the question of the re-definition of the 'working age person' to make the 'working age person' chronologically older.

Finally, decisions concerning the extension of work careers, use of early exit routes, and hiring new employees are made at the organizational level in conditions specific to each workplace. Indeed, age should be viewed and understood as part of the dynamics of the activity of work organizations and the formation of the labor market.

\section{References}

Aapola, S. (1999) Murrosikä ja sukupuoli. Julkiset ja yksityiset ikämäärittelyt. (Puberty and gender. Public and private definitions of age.) Helsinki: Suomalaisen kirjallisuuden seura.

Alasoini, T. (2010) Mainettaan parempi työ. Kymmenen väitettä työelämästä. (Better than its reputation. Ten theses on working life.) Helsinki: Taloustaito.

Andersen, T., B. Holmström, S. Honkapohja, S. Korkman, H. Söderström and J. Vartiainen (2007) The Nordic Model. Embracing globalization and sharing risks. Helsinki: The Research Institute of Finnish Economy.

Beck, U. (2000) The brave new world of work. Cambridge: Polity Press.

Bradley, H. (1996) Fractured Identities. Changing patterns of inequality. Cambridge: Polity Press.

Bradley, H., M. Erickson, C. Stephenson and S. Williams (2000) Myths at work. Cambridge: Polity Press.

Casey, C. (1995) Work, self and society. After industrialism. London \& New York: Routledge. 
Duncan, C. (2001) Ageism, early exit, and the rationality of age-based discrimination. In I. Glover and M. Branine (eds.) Ageism in work and employment. (p. 25-46). Ashgate, Aldershot: Stirling Management Series.

Forma, P., E. Tuominen and I. Väänänen-Tomppo (2004) Työssä jatkamisen haasteet yksityisellä ja julkisella sektorilla (The challenges of staying at work in the private and public sector.) In E. Tuominen (eds.) Eläkeundistus ja ikääntyvien työssä jatkamisaikeet. (Pension reform and intentions of staying at work among older workers.) (p. 23-82). Helsinki: Eläketurvakeskus, raportteja 37.

Gould, R. (1999) Varhaisen työmarkkinoilta poistumisen reitit. (Early exit pathways.) Helsinki: Eläketurvakeskus, monisteita 26.

Gould, R. (2002) Lisääkö yksilöllisen varhaiseläkkeen lakkauttaminen työssä jatkamista? (Does ending individual early pensions prolong staying at work?) In M. Takala and H. Uusitalo (eds.) Varhaiseläkkeet muuttuvat - mutta miten? Arvioita yksityisalojen eläkkeiden kehittämistä koskevan periaatesopimuksen vaikutuksista. (Early pensions change - but how?) (p. 13-29). Helsinki: Eläketurvakeskus, raportteja 30.

Gould, R. and L. Saurama (2003) From early exit culture to the policy of active ageing - the case of Finland. Helsinki: Finnish Centre for Pensions, Working Papers 4.

Government Programme (2011) Programme of Prime Minister Jyrki Katainen's Government 22.6.2011. URL: [http://www.vn.fi/hallitus/hallitusohjelma/pdf332889/en334743.pdf] (January 27, 2011).

Green, F. (2006) Demanding work. The paradox of job quality in the affluent economy. Princeton, NJ: Princeton University Press.

Guillemard, A. (2001) Continental welfare states in Europe confronted with the end of career inactivity trap: A major challenge to social protection in a ageing society. Paper prepared for the conference Rethinking social protection: Citizenship and social policy in the global age, Harvard University, 26-28 January 2001. URL: [http://www.ces.fas.harvard.edu/publications/docs/pdfs/Guillemard.pdf]. (December 14, 2010).

Hareven, T. (1995) Changing images of aging and the social construction of the life course. In M. Featherstone and A. Wernick, A. (eds.) Images of aging. Cultural representations of later life. (p. 119-135). London, New York: Routledge.

Hellsten, K. (1998) Varttuneet työntekijät ja hyvinvointivaltion muutospaineet. (Aged workers and pressures of change of the welfare state.) In M. Rajavaara (eds.) Työtä, eläkettä vai työttömyyttä? (Work, retirement or unemployment?) (p. 33-64). Helsinki: Kansaneläkelaitos.

Hulkko, L. and A. Pärnänen (2006) Miten osa-aikatyö valtasi palvelualat? (How did parttime work occupy the service sector?) Tieto\&trendit (4): 40-44.

Hytti, H. (1998) Varhainen työstä poistuminen - Suomen malli. (Early exit - the Finnish model.) Helsinki: Kansaneläkelaitos, sosiaali- ja terveysturvan tutkimuksia 32.

Hytti, H. (2002) Early exit from the labour market through the unemployment pathway in Finland. Helsinki: Central Pension Security Institute, Working Papers 2.

Ilmakunnas, S. and J. Rantala (2005) Oikeat asenteet vai onnistunut politiikka ikääntyneiden paremman työllisyyden taustalla? (Right attitudes or successful policy behind improved employment of older workers?) Työpoliittinen aikakauskirja (2): 74-81.

Ilmarinen, J., S. Lähteenmäki and P. Huuhtanen (2003) Kyvyistä kiinni. Ikäjobtaminen yritysstrategiana. (Age management as enterprise strategy.) Helsinki: Talentum.

Immergut, E. (1998) The theoretical core of the new institutionalism. Politics and society, 26(1): 5-34.

Järnefelt, N. (2003) Ikääntyvien työuran päättyminen lamavuosina ja nousukaudella. (Ending of work careers among older workers at the time of recession and economic upswing.) Helsinki: Tilastokeskus.

Julkunen, R. (2003) Kuusikymmentä ja työssä. (Sixty and at work.) Jyväskylä: SoPhi. 
Julkunen, R. (2008) Uuden työn paradoksit. Keskusteluja 2000-luvun työprosess(e)ista. (Paradoxes of new working life. Discussions on work processes in the 21st century.) Tampere: Vastapaino.

Kangas, O. (2000) Muurahaiset ja heinäsirkka. Australialaisten ja suomalaisten mielipiteet oikeudenmukaisista sosiaalieduista. (Ants and grasshoppers. Opinions of Finns and Australians on just social benefits.) Yhteiskuntapolitiikka, 65(5): 406-421.

Kohli, M. (1986) The life we forgot: a historical review of the life course. In V. W. Marshall (eds.) Later life. The social psychology of aging. (p. 271-303). London: Sage.

Kohli, M. and M. Rein (1991) The changing balance of work and retirement. In M. Kohli, M. Rein, A. Guillemard and H. Van Gunsteren (eds.) Time for retirement. Comparative studies of early exit from the labour force. (p. 1-35). Cambridge: Cambridge University Press.

Lallukka, K. (2003) Lapsuusikä ja ikä lapsuudessa. Tutkimus 6-12-vuotiaiden sosiokulttuurisesta ikätiedosta. (Childhood age and age in childhood. A study on the sociocultural knowledge of age.) Jyväskylä: Jyväskylän yliopisto, Studies in education, psychology and social research 215.

Lavikka, R. (eds.) (2004) Sopeudu ja vaikuta. Työn tietoistuminen ja sukupuolen pysyvyys. (Adapt and influence. The informationalization of work and the permanence of gender.) Tampere: Tampere University Press.

Lehto, A.-M. and H. Sutela (2008) Three decades of working conditions. Findings of Finnish Quality of Work Life Surveys 1977-2008. Helsinki: Statistics Finland.

Lehto, A.-M. and H. Sutela (2010) Ikääntyvien työpanos vahvassa kasvussa. (A positive trend in older workers' employment.) Tieto \& trendit 2: 18-22.

Liikanen, H. (1998) Työajan alapolitiikkaa korkean teknologian teollisuudessa. (Sub-policy of working time in the high tech industry.) Jyväskylä: Jyväskylän yliopisto.

The Many Faces of the National Programme on Ageing Workers. The Concluding Report on the Programme. (2002) Helsinki: Publications of the Ministry of Social Affairs and Health 14. URL: [http://pre20031103.stm.fi/english/tao/publicat/manyfaces/themanyfaces.pdf] (January 27, 2011).

McGoldrick, A. and J. Arrowsmith (2001) Discrimination by age: the organizational response. In I. Glover and M. Branine (eds.) Ageism in work and employment. (p. 75-95). Ashgate, Aldershot: Stirling Management Series.

Melin, H. and T. Mamia (2006) Suomalaiset työpaikat - tutkimuspaikkojen peruskuvaus. (Finnish work places - a basic description of research locations.) In T. Mamia and H. Melin (eds.) Kenen ehdoilla työ joustaa? Johtajien ja henkilöstön näkökulmia. (On whose terms will work flex? Views from managers and personnel.) (p. 13-36). Helsinki: Työministeriö.

Myles, J. (2002) A new social contract for the elderly? In G. Esping-Andersen, D. Gallie, A. Hemerijck and J. Myles (eds.) Why we need a new welfare state. (p. 130-172). Oxford: Oxford University Press.

Myrskylä, P. (2005) Työvoimamuutokset. (Changes in the labor force.) In P. Myrskylä (eds.) Tallella ikä eletty...Ikääntyminen tilastoissa. (Ageing in statistics.) (p. 53-87). Helsinki: Tilastokeskus..

Oden, B. (1996) Arbete, medelålders och äldre - en historisk översikt. In G. Aronsson and A. Kilbom (eds.) Arbete efter 45. Historiska, psykologiska och fysiologiska perspektiv på äldre in arbetslivet. (p. 23-40). Helsingborg: Arbetslivsinstitutet.

Pärnänen, A. (2011) Organisaatioiden ikäpolitiikat, strategiat, instituutiot ja moraali. (Age policies of organisations: strategies, institutions and morals.) Helsinki: Tilastokeskus.

Pekka, T. (2010) Keitä ne on ne työssä jatkajat? - Tutkimus eläkeaikeista ja työssä jatkamisen tukemisesta kunta-alalla. (Who are those who stay at work? - An investigation on the intentions to retire and on supporting staying at work at the municipal sector.) In P. Forma, 
R. Kaartinen, T. Pekka and J. Väänänen (eds.) Jaksaako jatkaa? Artikkeleita kuntatyön muutoksesta ja työssä jatkamisen tukemisesta kunta-alalla. (Are you able to continue? Articles on changes in work in municipality sector and supporting longer work careers.) (p. 111-142). Helsinki: Kuntien eläkevakuutus.

Phillipson, C. (1999) The social construction of retirement: perspectives from critical theory and political economy. In M. Minkler and L. Carroll (eds.) Critical gerontology. Perspectives from political and moral economy. (p. 315-327). New York: Baywood Publishing Company, Amityville.

Rantala, J. (2002) Ikääntyvien työttömyys ja työttömyyseläke. (Older workers' unemployment and unemployment pension.) Helsinki: Eläketurvakeskuksen raportteja 28.

Saari, P. (2008) Mistä kuntatyöntekijöiden lisääntyneet eläkeaikomukset johtuvat? (What causes the increase in intentions to retire among municipal workers?) In P. Forma, K. Harkonmäki, P. Saari and J. Väänänen (eds.) Ketkä tekevät kuntatyön tulevaisuudessa? Kuntatyö 2010 -tutkimus. (Who will do to work in the future? Work in Municipalities 2010 Survey.) (p. 61-74). Helsinki: Kuntien eläkevakuutus.

Schmidt, V. (2005) Institutionalism and the State. In C. Hay, D. Marsh and M. Lister (eds.) The State: Theories and Issues. (p. 98-117). Basingstoke: Palgrave.

Sennett, R. (1998) The corrosion of character. The personal consequences of work in the new capitalism. New York: Norton.

Siltala, J. (2004) Työelämän huonontumisen lybyt historia. (A short history of the worsening of working life.) Helsinki: Otava.

Strauss, A. and J. Corbin (1998) Basics of qualitative research. Techniques and procedures for developing grounded theory. Thousand Oaks: Sage Publications.

Taylor, P. E. and A. Walker (1994) The ageing workforce: employers' attitudes towards older people. Work, employment \& society, 8(4): 569-591.

Vaahtio, E. (2002) Ikä, rekrytointi ja ageismi. (Age, recruitment and ageism.) Helsinki: Työministeriö, Työpoliittinen tutkimus 244.

Viitala, R. (2002) Henkilöstöjobtaminen. (Human resources management.) Helsinki: Edita. Vincent, J. (1995) Inequality and old age. London: UCL Press. 